Allpanchis, año XLVIII, núm. 87. Arequipa, enero-junio de 2021, pp. 13-56.

ISSN impreso 0252-8835 / ISSN en línea 2708-8960

DOI: https://doi.org/10.36901/allpanchis.v48i87.1214

\title{
dossier
}

\section{El derecho canónico en Indias}

\author{
Carlos Salinas Araneda \\ Pontificia Universidad Católica de Valparaíso (Valparaíso, Chile) \\ carlos.salinas@pucv.cl \\ Código ORCID: 0000-0003-2070-7751
}

\section{RESUMEN}

Se presenta el derecho canónico vigente en América Latina durante el período hispánico en su doble vertiente del derecho canónico universal y del derecho canónico indiano, tanto in spiritualibus como su proyección y relaciones con el derecho de la monarquía.

Palabras clave: derecho canónico universal, derecho canónico indiano, patronato indiano 


\title{
Canon Law in Spanish America
}

\begin{abstract}
The canon law in Latin America during the Hispanic period is presented in its double perspective of Universal and American-Spanish Law, both in spiritualibus and its projection and relations with the monarchy's law.
\end{abstract}

KEYwORDs: universal canon law, Indian canon law, Indian patronage

CuAndo Cristóbal Colón Descubrió América el derecho canónico constituía un ordenamiento jurídico con una vasta tradición, por lo que, desde los primeros momentos, su vigencia se proyectó hacia los nuevos territorios sin ninguna discusión. Esto era reconocido por la misma modalidad con que las Indias occidentales se incorporaron a Castilla, definida por el ius commune como incorporación «accesoria», según la cual el derecho del reino incorporante se traspasaba al reino incorporado produciéndose, así, una común vigencia del mismo derecho en ambos territorios.

Desde el primer momento las fuentes universales del derecho canónico se proyectaron hacia Indias — principalmente el Corpus Iuris Canonici - regulando el actuar propio de la Iglesia en estas nuevas tierras, a las que se fueron agregando las que siguieron dictándose en los años sucesivos, especialmente el Concilio de Trento y toda la legislación complementaria a él. Pero, además, y sin perjuicio de la vigencia en Indias de ese derecho universal, rigió un derecho canónico propiamente indiano, surgido para responder a las necesidades peculiares de esta porción del Pueblo de Dios que se encontraba en las Indias de Occidente. En las páginas que siguen hago una breve presentación del derecho canónico vigente en las Indias de Occidente —en sus dos vertientes de universal e indiano- mostrando ese derecho en las fuentes que lo contenían, que fueron las usadas por quienes tuvieron la tarea de llevarlo a la práctica, lo que explica la extensa referencia bibliográfica final a los textos producidos durante esos años. 
Pero el derecho canónico indiano, además, ha sido y es objeto de estudio por los investigadores. La acotada extensión de un artículo me impide asomarme a esa extensa y valiosa literatura, para la cual remito a un par de avances bibliográficos, uno general, Duve (2012); otro para Chile, Salinas (1984, 2014); aparte de uno para la década de los años ochenta del siglo pasado, Salinas (1994a, 2014). En los últimos años, sin embargo, se ha producido un renovado interés por los temas canónico-indianos con aportes de indudable interés, por lo que me detendré brevemente en ellos.

\section{Derecho canónico universal}

\subsection{Corpus IURIS CANONICI}

Esta denominación empezó a generalizarse a partir de la segunda mitad del siglo XIV. El cuerpo de derecho canónico estaba compuesto por una serie de colecciones canónicas, la primera de las cuales fue el Decreto de Graciano (1140), al que le siguieron las Decretales de Gregorio IX (1234), el Liber Sextus de Bonifacio VIII (1298) y las Clementinas de Clemente V (1317). Posteriormente se incluyeron las Extravagantes de Juan XXII y las Extravagantes comunes, publicadas por Jean Chappuis en 1500. El Corpus Iuris Canonici fue objeto de una edición oficial a cargo de una comisión romana cuyos miembros fueron llamados «correctores romanos», instituida por san Pío V (1566-1572), y la edición de los correctores romanos fue publicada por Gregorio XIII (1572-1585) en 1582 (Friedberg, 1959). Hubo comentarios escritos en Indias, entre los que se puede mencionar el referido al libro II de las Decretales escrito por el obispo de Popayán, Feliciano de Vega (De Vega, 1633).

La vigencia y uso del Corpus canónico en América hispana fue principal in spiritualibus, pero también rigió en el fuero civil, y no solo por el régimen de patronato que reguló las relaciones entre la Iglesia y la Corona, sino porque la mayoría de los juristas castellanos, 
siguiendo una doctrina que se remonta a Bartolo y Baldo (Wolter, 1975, p. 43), se inclinó por dar preferencia subsidiaria respecto del derecho real al derecho canónico por sobre el romano (Del Corral, 1756 , p. 45). Basta ver las bibliotecas indianas de los hombres de leyes para advertir la presencia de ejemplares del Corpus Iuris Canonici en una parte no menor de ellas; un buen ejemplo son las bibliotecas de los oidores de la audiencia de Chile (Barrientos, 1992).

\subsection{Concilio de Trento}

Como la Iglesia empezó a discurrir por cauces históricos diversos, las normas del Corpus canónico debieron ser adecuadas a las nuevas realidades, especialmente después del Concilio de Trento. Eso hizo que, junto al Corpus, surgiera otro conjunto de fuentes, cuya nota común fue su carácter complementario del derecho anterior en un marco de creciente centralismo pontificio y una cada vez más acentuada espiritualización. Debido a que parte de la reforma disciplinar fue dejada a la actuación del papa, la labor legislativa de este fue intensa, no solo cumpliendo lo resuelto por el concilio, sino sobre otras materias. Esto originó la aparición de colecciones de actos pontificios llamadas «bularios», entre los que destaca el Magnum Bullarium Romanum iniciado por Laertius Cherubini (+1626), continuado por Girolamo Mainardi y después por Charles Cocquelines, que alcanzó treinta y dos volúmenes hasta 1758, con textos que van desde León I (440-461) hasta 1758, con varias ediciones, de las que la «novissima» es la de Luxemburgo iniciada en 1742, a la que se agregaron dos Continuationes que alcanzaron diecinueve y catorce volúmenes. Esto sin olvidar que existen bularios particulares referidos a territorios específicos o a órdenes religiosas.

\subsection{ACtuACiOnes DE LA CURIA ROMANA}

Junto a la labor pontificia fue intenso también el trabajo de las congregaciones de la curia romana; entre ellas destacó la Sagrada Congregación del Concilio instituida por Pío IV (1559-1565) 
para velar por la ejecución de los decretos tridentinos. Produjo un creciente número de decisiones que establecieron la interpretación ordinaria de los decretos disciplinares. Fue una de las principales fuentes del derecho canónico en estos siglos, lo que motivó la recopilación de sus actuaciones (Thesaurus, 1739; Pallottini, 1867-1983; Zamboni, 1812-1816). No menos importante fue la Sagrada Congregación de Propaganda Fide que fue elaborando un derecho misional, distinto del derecho común del Corpus, que fue igualmente recopilado, aunque de manera parcial (S. Congregationis de Propaganda Fide, 1893; De Martinis, 1888-1897). Sin embargo, la monarquía española impidió sistemáticamente la actuación de la Propaganda Fide en tierras americanas, alegando que, por concesiones pontificias, la tarea misionera en Indias era obligación de la Corona.

\section{Derecho Canónico indiano}

Junto al derecho canónico universal, con plena vigencia en Indias, existió también un derecho canónico surgido al calor de la nueva realidad que había empezado a vivir la Iglesia en las tierras descubiertas por Colón, un derecho canónico dirigido específicamente a esta porción del Pueblo de Dios. El derecho canónico presenta la particularidad de producirse en dos niveles diversos, cada uno con un legislador propio: un derecho canónico "pontificio», cuyo legislador propio es el romano pontífice, que puede crear normas para toda la Iglesia o sólo para una porción de ella; y un derecho canónico «particular», cuyo legislador propio es el obispo diocesano, que puede crear normas para la iglesia particular al frente de la cual se encuentra, derecho al que se agrega el elaborado por los concilios provinciales y sínodos diocesanos; derecho «particular» este que, para las Indias de Occidente, denominaré derecho canónico indiano «criollo». En ambos casos estamos frente a normas jurídicas vinculantes y obligatorias, y ambas dimensiones se dieron en la producción del derecho canónico indiano. 


\subsection{DeRECHO CANÓNICO INDIANO PONTIFICIO}

La actuación de los romanos pontífices en relación con las Indias occidentales se encuentra desde los primeros momentos posteriores al descubrimiento, pues la incorporación de las Indias a la Corona de Castilla y la actuación de la misma en torno a la Iglesia americana se produjo por las grandes concesiones pontificias producidas al calor del descubrimiento. Las primeras bulas pontificias fueron las bulas Inter caetera, de 3 y 4 de mayo de 1493, por las que el papa Alejandro VI (1492-1503) hizo donación a los Reyes Católicos de las tierras descubiertas por Colón y les concedió la exclusiva de su evangelización (García Gallo, 1957-1958, pp. 799-807; Morales, 1979, pp. 165-180; Metzler, 1991, pp. 71-75, 79-83; Hernáez, 1895, pp. 12-14); y la bula Eximiae devotionis, del 3 de mayo de 1493, que hizo extensivos a los mismos reyes los privilegios eclesiásticos concedidos en África a los reyes de Portugal, sin que, empero, pudiese hablarse de vicariato regio (García Gallo, 1957-1958, pp. 808-810; Metzler, 1991, pp. 89-91; Hernáez, 1885, pp. 15-16). Posteriormente, el mismo Alejandro VI, por la bula Eximiae devotionis sinceritas, del 16 de noviembre de 1501 (Fita, 1892, pp. 261-263; Hernáez, 1895, pp. 20-21; Garrido, 1979, pp. 330-331; Metzler, 1991, pp. 89-91), concedió a perpetuidad los diezmos de las Indias, con tal de que los monarcas españoles asignaren de antemano, en forma real y efectiva, dote suficiente a las iglesias que se hubieren de erigir en las Indias, con la que sus prelados y rectores se pudieren sustentar congruentemente y llevar las cargas que incumbieren a dichas iglesias, «y ejercitar cómodamente el culto divino a honra y gloria de Dios Omnipotente, y pagar los derechos episcopales». La Corona, no queriendo lucrar con estos dineros —uno de los impuestos que más le rendía - procedió a su devolución a la Santa Sede, la que los volvió a re-donar a la Corona española, determinándose finalmente que dos novenas partes de ellos quedarían en la Corona y las siete partes restantes se destinarían al sostenimiento de la Iglesia. El 8 de abril de 1510, a través de la bula Eximiae devotionis affectus, Julio 
II dispuso que los metales preciosos quedaran exentos del diezmo, correspondiendo íntegramente a la Corona (Fita, 1892, p. 288; Metzler, 1991, pp. 109-112).

Tras insistentes peticiones del rey Fernando el Católico, Julio II (1503-1513), mediante la bula Universalis Ecclesiae Regiminis, del 28 de julio de 1508 (Leturia, 1959, pp. 253-258; Hernáez, 1895, pp. 224-25; Metzler, 1991, I, pp. 104-107), concedió a los reyes de España el patronato universal de todas las iglesias de las Indias. Se trató de una concesión que no había existido nunca hasta entonces en el derecho canónico y comprendió todas las diócesis y dignidades eclesiásticas (Ayala, 1949; Bruno, 1967; Gutiérrez, 1954; De la Hera, 1959, 1970; Martínez, 1987; Salinas, 2009). El mismo monarca había solicitado que se le permitiera precisar los límites de las primeras diócesis, lo que no se le dio de manera general, pero los papas empezaron a concederlo para sedes concretas en las bulas de erección. Finalmente, mediante la bula Exponi nobis, del 9 de mayo de 1522, más conocida como Omnimoda (Hernáez, 1895, pp. 382-386; Levillier, 1919, pp. 41-44; Metzler, 1991, pp. 166-169), Adriano VI (1522-1523) estableció la forma canónica de envío de misioneros a Indias por los reyes de España, previa designación de sus superiores, lo que puso en manos de los monarcas hispanos la facultad de organizar en todos sus aspectos las expediciones misioneras al Nuevo Mundo, al tiempo que les dio una cierta prerrogativa para inmiscuirse en los asuntos internos de los institutos religiosos y vencer la resistencia de los provinciales de las órdenes de enviar a sus frailes a las tierras recién descubiertas. Esta preeminencia sería más tarde ampliada al eximirse a los religiosos que quisieren pasar a las Indias de la necesaria licencia de sus superiores. En la década de los años treinta del siglo XVI, el papado confirmó los anteriores privilegios y los Concilios Provinciales de Lima (1583) y México (1586), aprobados por el papa, reconocieron el patronato universal de los reyes en Indias. Años después, Benedicto XIV (1740-1758), en el concordato de 1753 
con España, indicaba expresamente que nunca se había controvertido el derecho de los reyes en las presentaciones para los beneficios de las Indias.

Sin perjuicio de lo anterior, muy pronto América empezó a mostrar su originalidad, una realidad que no siempre facilitaba la directa aplicación de un derecho elaborado para realidades tan diversas como eran las europeas. Surgió así la necesidad de ir elaborando un derecho complementario, de origen pontificio, que debió asumir, a veces con originalidad, las experiencias que la Iglesia empezaba a enfrentar (Hernáez, 1895; De Tobar, 1954, 1966; Metzler, 1991, 1995; García Gutiérrez, 1951). Al hacerlo, no solo elaboró normas a partir del derecho canónico ya existente, sino que no faltaron ocasiones en que, a partir de las nuevas experiencias indianas, terminó enriqueciéndose el mismo derecho canónico universal, como sucedió con la definitiva configuración de los privilegios paulino y petrino (Aznar, 1985, 1986). Con todo, la creación de un derecho indiano de corte pontificio quedó fuertemente limitada por el régimen de patronato imperante, al igual que su aplicación, toda vez que empezó a exigirse el «pase regio» para que dichas normas pudieran aplicarse en Indias (1538).

\subsection{DERECHO CANÓNICO INDIANO CRIOLLO}

\section{a) Concilios y sinodos}

Sin perjuicio de la vigencia del derecho universal, surgió también en Indias un derecho canónico particular que, especialmente a partir del Concilio de Trento, hizo aplicables a estas peculiares realidades la legislación universal. Su principal fuente estuvo en los concilios y sínodos que desde época temprana empezaron a celebrarse en América y a publicarse sus actas (Sáenz, 1754; Haroldus, 1673; De Villanuño, 1784, 1850; Tejada, 1849-1859), entre los que destacan el III Concilio Limense (Martínez y Gutiérrez, 2017) y el 
III Concilio Mexicano (Martínez, 2009), existiendo modernas ediciones de otros concilios provinciales indianos (De Utrera, 1940; Bantingue, 1957; Velasco, 1964).

Por diversos privilegios, la Santa Sede fue ampliando los plazos establecidos en Trento - los concilios debían reunirse cada tres años y los sínodos anualmente (Conc. Trid. sess. 24 c. 2 de ref.) para la reunión de los concilios provinciales — sucesivamente se ampliaron a cinco, siete y doce años- los que, en todo caso, por derecho común -D. 17 c. 1-7; Sixto V, const. Immensa, del 3 de febrero de 1587 - requerían la aprobación de la Santa Sede y, por disposiciones reales -Felipe II, real cédula del 31 agosto de 1560, recogida en Rec. Ind. 1, 8, 6-, también la del Consejo de Indias. No se varió, en cambio, la disciplina referida a los sínodos diocesanos, los cuales solo necesitaban la aprobación de la correspondiente autoridad civil local, salvo que «de ellos resultare haber alguna cosa contra nuestra jurisdicción y patronazgo real, u otro inconveniente notable», en cuyo caso debían suspender su ejecución y enviarlo al Consejo de Indias, que debía proveer lo conveniente (Recopilación 1, 8, 6). La misma Recopilación $(1,8,3)$ recordaba a los arzobispos y obispos que debían celebrar sínodo anualmente. De este modo se fue creando toda una legislación canónica diocesana local en Indias.

De estos sínodos, cuya nómina completa disponemos (García y García, 1985, pp. 384-386; Betancourt, 2013), se ha escrito que no son mayormente novedosos por cuanto se refiere a la disciplina de los clérigos y religiosos, aspectos estos en los que, salvo raras excepciones, reflejan el tradicionalismo, la meticulosidad y el rigor tridentinos y, en definitiva, medievales. La gran novedad de los sínodos americanos radicó en todo lo relacionado con el problema misional y trato que había que dar a los indios, aspecto este en que no había precedentes tridentinos ni medievales (García y García, 1982; Esponera, 1989; Salinas, 1990-1991; 2014).

Las limitaciones propias de un artículo me impiden hacer una relación de las modernas ediciones de algunos sínodos indianos, 
pero ellas se encuentran en el avance bibliográfico de Thomas Duve (2012), a la que remito al lector, así como la abundante literatura a que han dado origen estas asambleas eclesiales que no puedo ni siquiera enunciar, materia que, por lo demás, excede el objetivo de este estudio centrado más bien en las fuentes del derecho canónico en Indias. Con todo, hay que destacar la edición del sínodo de Buenos Aires de 1655 (Frías y Terráneo, 2012), del que se había hecho una presentación general con anterioridad (Capello, 1992) y del que se ha hecho una presentación resumida (Terráneo, 2019a). Tanto los concilios como los sínodos indianos han dado lugar a una amplia literatura sobre una temática variada, que queda recogida en la bibliografía recién aludida (Duve, 2012) y en un balance de la historiografía sobre concilios y sínodos indianos entre los años 1980 y 1996 (Salinas, 1998, 2014). Entre los trabajos más recientes se puede mencionar un estudio sobre los delitos y las penas en los sínodos indianos del territorio argentino (Terráneo, 2013a); a propósito del III Concilio Provincial Mexicano, un trabajo sobre la libertad como requisito para la profesión religiosa (Chico, 2018); en relación con el III Concilio de Lima, las apelaciones del clero de Charcas (Martínez, 2015); y en relación con el IV Concilio Provincial de México, un estudio sobre los principios de la salus animarum y la aequitas canonica como criterios interpretativos del derecho canónico indiano (Terráneo, 2017). A propósito de los sínodos chilenos se ha estudiado el estatuto jurídico de la acción catequística (Concha, 2010) y, últimamente, hay un nuevo trabajo sobre los sínodos limeños de Santo Toribio de Mogrovejo (Grignani, 2019).

\section{b) Actas de visita}

Otra fuente importante de este derecho particular indiano fueron los autos de visita dictados por los obispos o los visitadores, con ocasión de las visitas a sus obispados. Se trata, sin embargo, de una fuente apenas estudiada (Basto, 1957; Camus, 1994; Walker, 1994a, 1994b). Entre estas destacan las visitas de idolatrías realizadas 
en Lima por el arzobispo Lobo Guerrero que, en opinión de alguna autora, constituyen una institución propia del derecho canónico indiano (Cordero, 2011, 2016; Guibovich, 2011). Recientemente se ha estudiado la visita canónica a los libros parroquiales en Buenos Aires, entre 1603 y 1750 (Frías, 2015), las visitas pastorales a parroquias indígenas andinas (Ramos, 2016) y, últimamente, la visita pastoral del obispo Mariano Martí a la diócesis de Caracas entre 1771 y 1784 (Dávila-Mendoza, 2019).

\section{c) Derecho de regulares, párrocos y misiones}

Los religiosos arribaron a América desde los primeros momentos de la presencia hispana en el continente, y ellos fueron protagonistas importantes de la tarea evangelizadora asumida por la Corona, por lo que, el derecho canónico referido a ellos ocupa un lugar particular, tanto el referido a los religiosos en general literatura a la que, por razones de espacio, no me puedo referir-, como el referido específicamente a los regulares en Indias (De Parras, 1783). Un lugar no menor ocupa la literatura dirigida a los párrocos de Indias, la que ofrece gran interés canónico, pero también para el mundo secular en cuanto informan a los párrocos para que puedan orientar jurídicamente a los naturales (De Molina, 1585-1603; Carrillo, 1596; Bautista, 1601; De la Peña, 1668-1771; De Avendaño, 1668-1687; Almoguera, 1671; Pérez de la Cerda, 1679; De Zárate, 1736 [1845]; Aragón, 1894; De las Casas, 1958; Barinas, 1955; Chinchilla, 1959; Rubiños, 1936). Tarea de los párrocos era llevar los libros parroquiales que, al modo de los modernos registros del Estado, dejaban constancia y daban autenticidad a determinados hechos o situaciones como el bautismo, el matrimonio y la defunción, libros cuya importancia ha sido puesta de relieve (Konetzke, 1946; Barreda, 1957; Díaz, 1962). Son también interesantes para el derecho los libros de técnicas misionales (Focher, 1574; 1960; De Zurita, 1586; Acosta, 1589; De Sandoval, 1627). Se conserva inédita una obra de fray Antonio Comajuncosa titulada El comisario prefecto 
de misiones instruido del que se ha estudiado, en una tesis doctoral, los elementos de derecho canónico indiano que se encuentran en ella (Gonzáles, 2012).

\section{d) Otras fuentes del derecho canónico indiano}

En las páginas que anteceden he intentado ofrecer un panorama general del derecho canónico vigente en Indias durante el período hispano, tanto del derecho canónico universal como del propiamente indiano, centrando mi atención en las fuentes editadas del mismo y los principales estudios hechos a partir de ellas. Las limitadas posibilidades de un artículo impiden abordar las temáticas específicas tratadas por dichos cuerpos normativos, cuya literatura puede encontrarse en las bibliografías citadas; no obstante, más adelante presento un panorama general de la literatura ius histórica de los últimos años.

Hay, además de las anteriores, otras fuentes de derecho canónico indiano que regularon el actuar de hombres y mujeres en las tierras americanas de esos años, como las reglas de hermandades y cofradías, las consuetas de las catedrales y los aranceles eclesiásticos, los diferentes autos dictados para mantener el orden en las diócesis, los decretos locales de indulgencias, los ordos y rituales ceremoniales, y otras. Se trata de fuentes, por lo general manuscritas, guardadas en archivos y colecciones documentales de las que ya hay estudios antiguos y recientes, pero que están a la espera de futuras investigaciones que permitan conocer mejor espacios, comportamientos y lugares donde se entretejieron las normas con la vida social y religiosa de los fieles en Indias, normas que, en su tiempo, marcaron el ritmo de vida de personas y comunidades (Martínez de Sánchez, 2008). Estudios recientes han abordado las consuetas de la catedral de México (Terráneo, 2011) y Lima (Grignani, 2019), las cofradías (Arizmendi, 2009), los aranceles eclesiásticos (Frías, 2006-2007, 2008), pero, al tiempo que se ha puesto de relieve su riqueza, se ha alertado acerca del riesgo de su uso (Frías, 2014). 


\section{e) Los justos títulos}

Hay otro ámbito en que el derecho canónico ocupó un lugar de importancia frente al tema indiano. Cuando en el universo jurídico europeo empezaba a proyectarse el humanismo, en las penínsulas de Italia y de España se produjo un renacer de la escolástica medieval, que se presentaba amoldada a los nuevos tiempos y que es conocida como «la segunda escolástica». Su arco cronológico abarca el siglo XVI hasta bien entrado el XVII, y muy ligado a este renacer está el florecimiento del tomismo. Entre los iniciadores de la segunda escolástica pueden situarse el cardenal Cayetano, Tomás de Vio (1468-1534) o Conrado Koellin (+1537). Pero fue en España donde se encontraron los autores más importantes, un grupo de teólogos que, con algunos juristas, formaron lo que un autor ha llamado los «Magni hispani» (Hervada, 1987, p. 217): los teólogos juristas del siglo XVI o escuela española del derecho natural (Giacon, 1943-1950; Ambrosetti, 1951, 1973; Carro, 1944; Thieme, 1954, 1969-1970). El movimiento fue iniciado por Francisco de Vitoria (1492-1546) y llegó a su culminación con Francisco Suárez (1548-1617). Entre los juristas no pueden silenciarse autores de la talla de Fernando Vázquez de Menchaca (1512-1569), Diego de Covarrubias y Leyva (1512-1577) o Martín de Azpilcueta (1492-1596).

Vitoria era profesor en la Universidad de Salamanca, donde llegaban todas las inquietudes del Nuevo Mundo, por lo que fue un testigo privilegiado de lo que estaba sucediendo en Indias: el derecho común se mostraba insuficiente y, en ocasiones, injusto, para asumir las nuevas realidades. Se trataba de un derecho concebido para un mundo entendido como la «cristiandad» en que, no obstante las diferencias, todos compartían la misma fe y que ahora pretendía aplicarse en un mundo donde esa igualdad se había quebrado. Impulsado por la necesidad de solucionar los problemas surgidos con la conquista, se trataba ahora de buscar principios e instituciones que permitieran la convivencia de pueblos con fe diferente: cristianos y no cristianos; un derecho superior de carácter 
puramente racional. Este afán de buscar soluciones que iluminaran los problemas de la conquista a partir de un derecho común de carácter ius-racionalista dio origen a una rama que podemos considerar propiamente «indianista»: integrada por discípulos de los maestros salmantinos, destacaron en América, en la cátedra de las nacientes universidades y en el gobierno espiritual o civil, el jesuita José de Acosta en Lima (1540-1600), el agustino Alonso de la Veracruz en México (1507-1584), su hermano de hábito y después obispo Juan de Zapata y Sandoval (+1630), y el también agustino y obispo Luis López de Solís (1534-1606). Estos y muchos más trataron de llevar a la práctica los principios que habían aprendido en las aulas peninsulares (Salinas, 1994b). La condición de clérigo de muchos de ellos les permitió, a través de los sínodos y concilios de la Iglesia en Indias, desarrollar, contrastar y adecuar lo que habían aprendido de sus maestros, revisando las instituciones más importantes que condicionaron y dominaron durante la primera conquista. Todo este proceso de reflexión ha sido considerado «una de las páginas más luminosas para la filosofía de la historia americana» (Pereña, 1987, vi) y en ella los canonistas y el derecho canónico ocuparon un lugar de honor.

\section{f) Legislación real en materias eclesiales: el patronato indiano}

Junto a las normas emanadas en el ámbito propiamente canónico hay que agregar en Indias las normas reales que abordan en forma explícita el tema eclesial. En efecto, las especiales relaciones IglesiaEstado que se dan durante este tiempo, calificadas genéricamente como «regalismo», permitieron que los Estados elaboraran normas para regular los más diversos aspectos de la vida de la Iglesia. Para Indias esto tuvo una especial significación desde los primeros años, pues en virtud de la bula Universalis Ecclesiae Regiminis (1508) ya citada, Julio II (1503-1513) concedió a los reyes castellanos el patronato real, lo que significó no solo el derecho de presentación de obispos y altos dignatarios eclesiásticos sino también, y en virtud de otros 
privilegios, el derecho de cobrar los diezmos. Como contrapartida, la Corona asumió la obligación de mantener y dotar a la Iglesia de lo necesario para el cumplimiento de sus tareas espirituales. Existe, pues, una abundante legislación real relativa a lo eclesial (Cedulario, 1920-1921; Urteaga y Angulo, 1924-1942), un buen ejemplo de lo cual es el libro primero de la Recopilación de Leyes de Indias. La literatura sobre el tema fue abundante en el período indiano (Álvarez de Abreu, 1769; Cirer y Zerda, 1736; De Rivadeneyra, 1755; De Solórzano, 1629-1639, 1647; De Villarroel, 1656-1657; Frasso, 1677-1679; Morales, 1747; García Pérez de Aciel, 1624; Salgado de Somoza, 1646; De la Cueva, 1749; Bravo, 1750) y ha seguido en la actualidad (Ayala Delgado, 1949; Bruno, 1967; Cantelar, 1989; De la Hera, 1959, 1970, 1980, 1992; De la Hera-Martínez de Codes, 1987; Leturia, 1959; García Gutiérrez, 1941; Gómez Zamora, 1897; Gutiérrez de Arce, 1954; Martínez de Codes, 2008; Quesada, 1910; Sánchez Bella, 1990; Scheils, 1961; Albani, 2012, 2014; PizzorussoSanfilippo, 1998; Sanfilippo-Pizzorusso, 2004; Pizzorusso, 2014).

Esta preocupación de la Corona por la difusión de la fe como el primero y principal fin del gobierno temporal de las tierras y pueblos de ultramar, al que había de subordinar todo lo demás, ha llevado a algún autor a calificar al Estado español de esta época como un auténtico Estado misional: si dentro de la historia de la Iglesia, la Edad Moderna es una etapa de expansión sin paralelo, en la que la difusión de la fe fuera de Europa hace brillar su catolicidad de un modo hasta entonces inédito, ello se debe, en no poca parte, a la contribución que prestaron las monarquías española y portuguesa a la evangelización de los pueblos indígenas de América y Filipinas. En este sentido, pese a los defectos y limitaciones de toda obra humana, «la forma en que por más de tres siglos colaboraron allí los dos poderes, espiritual y temporal, en la tarea evangelizadora, merece ser tenida como una de las más fructuosas que la Iglesia ha conocido en sus dos mil años de existencia» (Bravo Lira, 1992). 


\section{g) Vigencia subsidiaria del derecho canónico en el fuero civil}

Además de su vigencia en el ámbito eclesial, el derecho canónico era uno de los dos principales integrantes del ius commune, por lo que igualmente su vigencia se proyectaba hacia el ordenamiento secular. En efecto, de acuerdo con la doctrina común, según he dicho, el derecho canónico tenía una aplicación subsidiaria si la materia, siendo solo del fuero secular, no encontraba regulación en el derecho real al que se recurría primeramente a título de principal.

Esta misma condición de ser uno de los dos integrantes universales del ius commune hizo que el derecho canónico fuera enseñado en las universidades y formara parte de la educación que recibían los juristas civiles en Indias. Hay quien sostiene que la primera clase de derecho impartida en Indias fue de derecho canónico. En efecto, el 25 de enero de 1553, día en que se conmemora la conversión de San Pablo, se hizo la solemne apertura de la Universidad de México, de la que el apóstol había sido declarado patrono. Cinco meses después, el 3 de junio de ese año, se inauguraron los cursos con una ceremonia académica y, dos días después, los maestros dieron sus primeras lecciones, correspondiendo la primera al catedrático de prima de cánones. Con todo, si no fue la primera clase de derecho en Indias, al menos parece que lo fue en dicha universidad (Schroeder, 1992, p. 90). Es por lo que, frecuentemente, se encuentran obras canónicas en las bibliotecas de los juristas de la época, como he señalado (Barrientos, 1984, 1993). La enseñanza y aplicación del derecho canónico, tanto in spiritualibus como in temporalibus, permitió la edición de obras que presentaban el derecho canónico en visiones de conjunto (Murillo, 1743, 2005; Morel, 1776). Y, como el derecho canónico del período indiano proyectó su vigencia por todo el siglo XIX, surgieron en las repúblicas americanas manuales decimonónicos que recogieron ese derecho tanto universal como indiano (Donoso, 1848-1849; Roa, 1862; DevotiCorominas, 1871; Vera, 1887). 


\section{LOS RECIENTES ESTUDIOS SOBRE DERECHO CANÓNICO INDIANO}

En los últimos años ha ido surgiendo una moderna literatura histórico-jurídica en la que ha ocupado un lugar destacado un grupo de investigadores en torno al Instituto de Historia del Derecho Canónico Indiano en la Universidad Católica Argentina, al alero del cual se han celebrado algunas jornadas de estudio, de las que se han publicado las actas de tres de ellas, las correspondientes a las segundas (Terráneo y Moutin, 2015), las terceras (Terráneo y Moutin, 2017) y las cuartas jornadas (Terráneo y Moutin, 2018). Un útil instrumento de trabajo, puesto a disposición de los investigadores, ha sido un avance bibliográfico para el estudio del derecho canónico indiano (Duve, 2012) que, en palabras de su autor, «quiere ser un primer acercamiento a la bibliografía sobre la historia del desarrollo del Derecho Canónico durante la dominación española-portuguesa del continente americano y de los años siguientes a los procesos emancipatorios»; los registros se ordenan por orden alfabético de autores, sin mayores divisiones.

Las temáticas abordadas por los trabajos publicados en la última década, además de los enunciados en las páginas que anteceden, es variada, con aportes tanto de carácter general, como referidos a instituciones en particular. Al no poder hacer un análisis más detenido de los mismos, me limito a enunciarlos, a fin de mostrar la variada temática que muestra la investigación actual. Entre lo más generales, a propósito de las fuentes del derecho canónico indiano se ha hecho una aproximación que su autor entiende como unos apuntes liminares (González, 2009-2010). A partir del ius tridentinum se han estudiado sus tres variaciones, a saber, el derecho canónico común, el derecho canónico indiano y el derecho canónico misionero (Sastre, 2019). Se puede mencionar también un estudio sobre teología moral y probabilismo jurídico, en el que el autor ofrece una mirada, entre otros, del jesuita Diego de Avendaño (Ruiz, 2017) y el uso canónico de los santos padres (Giudice, 2015). 
Referido más específicamente al derecho canónico indiano se ha planteado una hipótesis sobre su naturaleza y contenido (Terráneo, 2013b), afirmándose la naturaleza propiamente eclesial del mismo, generado con autonomía respecto del derecho de la monarquía, el que, si bien abordaba materias eclesiales, no debería ser considerado derecho canónico indiano. La enseñanza del derecho canónico en Indias también ha sido tratada (Terráneo, 2017), tema del que se ha escrito acerca de los textos utilizados en su enseñanza en Chile (Salinas, 2000). Desde otra perspectiva es el estudio de temáticas eclesiales y religiosas en las actas de cabildos seculares de la frontera oriental del virreinato del Río de la Plata (Flores, 2018). Se ha estudiado también la proyección en Indias de la literatura canónica veneciana (Dougnac, 2011-2012) y al canonista peruano Feliciano de Vega (Barrientos, 1999-2000).

Si nos aproximamos a la literatura más particularizada a partir de los cinco libros de las Decretales, en lo que refiere al primero de ellos, «Iudex», nos encontramos, en materia de fuentes del derecho, con estudios sobre la costumbre (Terráneo, 2014) y la legislación eclesiástica de la arquidiócesis de Santa Fe en el Nuevo Reino de Granada (Cobo, 2018). De los obispos se ha escrito acerca de su nombramiento en Chile (Salinas, 2016), sus facultades decenales (González, 2018), su expulsión (Garavelli, 2015) y sus atribuciones judiciales durante la visita canónica (Terráneo, 2016a). También se han dado algunas contribuciones recientes sobre jueces (Terráneo, 2015; Moriconi, 2019) y abogados (Honores, 2019) y, a propósito de los cabildos catedralicios, sobre los adjuntos (Terráneo, 2018).

Vinculados al libro II de las Decretales, «Iudicium», hay que mencionar los numerosos trabajos del profesor Nelson Dellaferrera referidos a los tribunales y procesos, todos ellos recogidos en la bibliografía de Duve (2012); más recientemente se ha publicado una serie de artículos referidos al derecho canónico indiano, a las relaciones de la justicia eclesiástica con el poder secular y a la apli- 
cación del derecho en la vida de los virreinatos americanos, con especial atención a la población indígena (De Zaballa, 2011). Existe también una valoración historiográfica sobre la administración de la justicia eclesiástica en el Río de la Plata entre los siglos XVII y XVIII con una nutrida bibliografía (Moriconi, 2012); estudios sobre justicia eclesial que también se han realizado para Nueva España, algunos vinculados a la materia matrimonial (Traslosheros, 2014, 2016; Traslosheros-Zaballa, 2010; Siegrist, 2011, 2012). Siempre sobre procesos, se ha escrito sobre el procedimiento breve (Moutin, 2017) y el proceso de nulidad matrimonial en el derecho canónico indiano y sus puntos de contacto con recientes reformas procesales en el ámbito de dicho proceso en la legislación canónica actual (Terráneo, 2016b).

Sobre las materias legisladas en el libro III de las Decretales, «Clerus», se ha escrito sobre confesión (Ferreira, 2014) y predicación (Ferlán, 2019), así como de religiosos (Chico, 2018) y de monasterios (Pérez, 2019). Hay algunos artículos sobre patronato, uno en las Cortes de Cádiz (Westermeyer, 2016), otro sobre el patronato en el paso de la monarquía a la república en Chile (Enríquez, 2019) y un tercero sobre una real cédula de Carlos III, que dispuso recoger en las Indias un breve de Clemente XIV en favor de los jesuitas (González, 2015). Además, se ha escrito sobre administración diocesana (Mazzoni, 2019) y desamortización en México (Vázquez, 2018).

En materia de matrimonio, al que se dedica el libro IV de las Decretales, «Connubia», es de particular interés la edición del Tratado de los impedimentos matrimoniales del jesuita Fabián Hidalgo (Hidalgo, 2005). En 2016 la Revista Complutense de Historia de América dedicó un dossier al «Matrimonio en los siglos XVI-XVIII: derecho canónico, conflictos y realidad social», que profundizó en la práctica del matrimonio postridentino en los virreinatos de Lima y México, tanto entre la población indígena como española y de castas; tras la introducción (De Zaballa, 2016a), se abordó su celebración en Lima y Charcas (Latasa, 2016a), las dispensas para matrimonios 
secretos (Siegrist, 2016), el matrimonio de los indios en México (De Zaballa, 2016b) y las separaciones, divorcios y nulidades en la audiencia de Charcas (Presta, 2016). Otros estudios han abordado las dispensas de amonestaciones en Lima (Latasa, 2008), la libertad para casar (Latasa, 2016b), las promesas y engaños (De Zaballa, 2016c) y el parentesco por afinidad en el siglo XIX, período histórico en que se proyecta la vigencia del derecho canónico vigente en Indias en el período hispano (Siegrist, 2015).

Tampoco han faltado en estos últimos años estudios referidos al derecho penal indiano, el libro $\mathrm{V}$ de las Decretales, «Crimen»: el derecho canónico en la justicia penal del Río de la Plata del siglo XVIII en delitos como el aborto, infanticidio, adulterio, herejía, y otros (Olaza, 2017), el asilo en sagrado (Olaza, 2018) o el régimen penal de las asambleas eclesiásticas de santo Toribio de Mogrovejo (Terráneo, 2019b). Hay que mencionar también una valoración crítica que se ha hecho del Cursus juris canonici hispani et indici de Pedro Murillo Velarde como contribución fundamental a la literatura penal indiana (Rodríguez, 2019), Curso del que se ha hecho una nueva edición (México 2005).

Como puede advertirse, el interés por los estudios de derecho canónico indiano muestra una gran vitalidad, la que, además de la literatura apuntada, que no pretende ser exhaustiva, presenta dos logros que no pueden omitirse: un Diccionario histórico de derecho canónico en Hispanoamérica y Filipinas. Siglos XVI-XVIII, que lleva adelante el Max-Planck-Institut für europäische Rechtsgeschichte, del que se han publicado en línea algunas voces. Y un muy reciente manual (Terráneo, 2020) que, en algo más de setecientas páginas, presenta la más completa exposición moderna del derecho canónico que rigió en las Indias. 


\section{A MOdo DE CONCLUSIÓN: LA VIGENCIA DEL DERECHO CANÓNICO INDIANO DESPUÉS DE LA INDEPENDENCIA DE LOS PAÍSES LATINOA- MERICANOS}

Producida la independencia, la vigencia del derecho canónico indiano continuó a lo largo del siglo XIX. Por lo pronto, la revolución de la independencia había sido un acontecimiento político desarrollado en los ambientes civiles, y si bien los hechos que llevaron a la independencia política de España afectaron en grado no menor a la Iglesia en América, el nuevo estado de cosas no afectó al derecho propio de la Iglesia que, en consecuencia, siguió rigiendo en los años postindependencia. Contribuyó a esta continuada vigencia el régimen de patronato del que las autoridades republicanas se sintieron herederas, con la consiguiente intervención en los asuntos eclesiales, lo que hizo que no se celebraran concilios ni sínodos por la injerencia que en ellos pretendían las nuevas autoridades, no pocas veces contrarias a la Iglesia; por todo ello las grandes asambleas indianas, como el III Concilio Limense, vio prolongada su vigencia hasta finales del siglo. Pero el influjo del derecho canónico indiano estaba llamado a prolongarse aún más allá del siglo XIX.

En efecto, en 1904, a poco de haber iniciado su pontificado, el papa Pío X decidió sustituir el viejo Corpus Iuris Canonici por un moderno Codex Iuris Canonici. A pesar de ello, el pontífice no quiso que el nuevo Codex sea solo una obra de expertos, sino que dispuso al mismo tiempo que se realice una consulta a todo el episcopado para que ellos, con la experiencia que les proporcionaba el uso del derecho canónico en el gobierno cotidiano de sus iglesias particulares, hicieran las sugerencias que consideraren pertinentes al derecho canónico vigente. En tal ocasión fueron consultados todos los obispos latinoamericanos y, en las propuestas que ellos formularon en respuesta a la consulta romana, apareció el derecho canónico indiano, pues algunas de sus proposiciones hundían sus 
raíces, a veces manifestado expresamente, en el derecho canónico desarrollado durante el período hispánico. Se trató de una proyección hasta ahora poco conocida, pero que es expresión de la vitalidad que había alcanzado el derecho canónico indiano (Salinas, 2017, 2010).

\section{REFERENCIAS}

Albani, Benedetta (2012). «Nuova luce sulle relazioni tra la Sede Apostolica e le Americhe. La pratica della concessione del "Pase regio" ai documenti pontifici destinati alle Indie». En: C. Fernal (ed.). Eusebio Francesco Chini e il suo tempo. Una riflessione storica. Trento: F. B. K. Press, pp. 83-102.

Albani, Benedetta (2014). «Un nuncio per il Nuovo Mundo. Il ruolo della nunciatura di Spagna come istanza di giustizia per i fedeli americani tra Cinque e Seicento». En: P. Tusor y M. Sanfilippo (eds.). Il papato e le Chiese locali. Studi / The Papacy and the local Churches. Studies. Viterbo: Sette Città, pp. 257-286.

Almoguera, Juan (1671). Instrucciones de sacerdotes, con aplicación individuada a curas y eclesiásticos de las Indias. Madrid: Por Julián Paredes.

Álvarez de Abreu, Antonio Josef (1769). Victima real legal: discurso único juridico-bistórico-político sobre que las vacantes mayores y menores de las Indias Occidentales pertenecen a la Corona de Castilla y León con pleno y absoluto dominio. Madrid: Por Andrés Ortega.

Ambrosetti, Giovanni (1951). Il diritto naturale della Riforma Cattolica. Milán: Giuffrè Editore.

Ambrosetti, Giovanni (1973). «Diritto privato ed economía nella seconda scolastica». En: Paolo Grossi (ed.). La seconda scolastica nella formazione del diritto privato moderno. Quaderni per la Storia del Pensiero Giuridico Moderno, vol. 1. Milán: Giuffrè Editore, pp. 23-52.

Aragón Lasierra, Victorian (1894). Colección de la legislación civily penal de España y Ultramar necesaria para el desempeño de la cura parroquial, adaptada 
a las actuales circunstancias del sacerdote. Segunda edición a cargo de F. Delgado. Huesca: Tip. Blasco y Andrés.

Arizmendi Echecopar, Emilio (2009). «Un caso de derecho canónico indiano: el marco jurídico de la cofradía limeña de finales del virreinato». Ita Ius Esto, vol. 2, pp. 137-198.

Ayala Delgado, Francisco Javier (1949). «Iglesia y Estado en las leyes de Indias». Estudios Americanos, vol. 3, pp. 417-460.

AzNAR, Federico (1985). La introducción del matrimonio cristiano en Indias: aportación canónica (s. XVI). Salamanca: Bibliotheca Salmanticensis Estudios.

Aznar, Federico (1986). «El matrimonio en Indias. Recepción de las Decretales X 4.19.7-8». Revista de Estudios Histórico-Jurídicos, vol. 11, pp. 13-42.

Bantingue, Pedro N. (1957). The provincial Council of Manila of 1771, its text followed by a commentary on Actio II «De episcopis». Washington: Catholic University of America Press.

Barinas, A. (1955). «Documento sobre casos morales de Indias». Missionalia Hispanica, vol. 12, pp. 555-570.

Barreda, Felipe (1957). «Libros parroquiales de ciudades del Perú». Revista del Instituto Peruano de Investigaciones Genealógicas, vol. 10, pp. 79-85.

Barrientos Grandón, Javier (1992). La cultura jurídica en el reino de Chile. Bibliotecas de ministros de la real audiencia de Santiago (s. XVII-XVIII). Santiago: Publicaciones Universidad Diego Portales.

Barrientos Grandón, Javier (1993). La cultura jurídica en la Nueva España. México: Universidad Nacional Autónoma de México.

Barrientos Grandón, Javier (1999-2000). «Un canonista peruano del siglo XVII: Feliciano de Vega (1580-1640)». Revista Chilena de Historia del Derecho, vol. 18, pp. 101-118. 
Basto Girón, L. J. (1957). «Los legajos de visitas del archivo arzobispal de Lima, siglo XVII». Documenta, Lima, vol. 3, pp. 349-425.

Bautista, Juan (1600). Advertencia para los confesores de naturales. México: En el convento de Santiago Tlatilulco. Por M. Ocharte.

Betancourt Serna, Fernando (2013). «Fuentes del Ius Canonicum Particulare español e indiano». Glossae. European Journal of Legal History, vol. 10, pp. 95-107.

Bravo de Lagunas y Castilla, Pedro J. (1750). Discordia de la concordia. Lima: s/e.

BRAVO LiRA, Bernardino (1992). «La epopeya misionera en América y Filipinas: contribución del poder temporal a la evangelización». En: Pontificia Commissio pro America Latina. Historia de la evangelización de América. Trayectoria, identidad y esperanza de un continente. Ciudad del Vaticano: Libreria Editrice Vaticana, pp. 65-75.

Bruno, Cayetano (1967). El derecho público de la Iglesia en Indias. Salamanca: Consejo Superior de Investigaciones Científicas; Instituto San Raimundo de Peñafort.

Camus Ibacache, Misael (1994). «Frecuencia y estilo de la visita pastoral en Chile, período hispánico». Anuario de Historia de la Iglesia en Chile, vol. 12, pp. 9-38.

Cantelar Rodríguez, Francisco (1989). «Patronato y vicariato regio español en Indias». En: Derecho canónico y pastoral en los descubrimientos lusoespañolesy perspectivas actuales. Salamanca: Bibliotheca Salmanticensis, pp. 57-102.

Capello, Hugo (1992). «El sínodo de Buenos Aires celebrado por el obispo Mancha en 1655». Revista Española de Derecho Canónico, vol. 49, pp. 51-76.

Carro, Venancio (1944). La teología y los teólogos-juristas españoles ante la conquista de América. 2 volúmenes. Madrid: Escuela de Estudios Hispanoamericanos de la Universidad de Sevilla. 
Carrillo, M. (1596). Memorial de confesores. Zaragoza: Por Ximeno Sánchez.

Cirer y Zerda, Miguel (1736). Propugnáculo histórico-canónico-político-legal, que descubre los fondos de la más preciosa piedra de la Corona de España. Madrid: s/e.

Cobo Betancourt, Juan Fernando (2018). «Reflexiones sobre la edición de la legislación eclesiástica de la arquidiócesis de Santa Fe en el Nuevo Reino de Granada». En: Sebastián Terráneo y Osvaldo Moutin (coords.). IV Jornadas de Estudio del Derecho Canónico Indiano. Junín: Ediciones de las Tres Lagunas, pp. 73-92.

Colección (1920-1921). Colección de documentos históricos del arzobispado de Santiago: I-II, Cedulario 1548-1720. Santiago: Imprenta Chile.

Concha Contreras, María Inés (2010). «El estatuto jurídico de la acción catequística en la legislación sinodal chilena del período indiano». Revista Chilena de Historia del Derecho, vol. 22, pp. 417-434.

Cordero, Macarena (2011). «Formación de una institución: las visitas de idolatrías». En: Ana de Zaballa (coord.). Los indios, el derecho canónico y la justicia eclesiástica en la América virreinal. Madrid; Frankfurt am Main: Iberoamericana-Vervuert, pp. 109-152.

Cordero, Macarena (2016). Institucionalizar y desarraigar. Las visitas de idolatrías en la diócesis de Lima, siglo XVII. Lima: Pontificia Universidad Católica del Perú; Instituto Riva-Agüero.

CHIco, Sandra (2018). «La libertad como requisito canónico para la profesión religiosa en el tercer Concilio Provincial Mexicano». En: Sebastián Terráneo y Osvaldo Moutin (coords.). IV Jornadas de Estudio del Derecho Canónico Indiano. Junín: Ediciones de las Tres Lagunas, pp. 51-72.

Chinchilla Aguilar, E. (1959). «Un confesionario del siglo XVII, escrito por fray Antonio del Saz ofm». Antropología e Historia de Guatemala, vol. 11, pp. 32-39. 
Danwerth, Otto, Benedetta Albani y Thomas Duve (eds.) (2019). Normatividad e instituciones eclesiásticas en el virreinato del Perú, siglos XVI-XIX. Frankfurt am Main: Max Planck Institute for European Legal History.

DÁvila-Mendoza, Dora (2019). «La visita pastoral del obispo Mariano Martí a la diócesis de Caracas 1771-1784. Fuentes y temas para un estudio social». Anuario de Historia de la Iglesia, vol. 28, pp. 101-131.

De Acosta, José (1589). De promulgando Evangelio apud barbaros seu de procuranda indorum salute. Salamanca: Apud Guillelmum Foquel.

De Avendaño, Diego (1668-1686). Thesaurus indicus seu generalis instructor pro regimine conscientiae in iis quae ad Indias spectant. Amberes: Meursio.

De la Cueva Ponce de León, Alonso (1749). Concordia de la discordia sobre un punto grave de inmunidad eclesiástica. Lima: En la imprenta de la Calle de Palacio.

De la Hera, Alberto (1959). «El regio patronato español de las Indias en las bulas de 1493». Anuario de Historia del Derecho Español, vol. 29, pp. 317-349.

De la Hera, Alberto (1963). El regalismo borbónico y su proyección indiana. Madrid: Ediciones Rialp.

De La Hera, Alberto (1970). «La legislación del siglo XVIII sobre el patronato indiano». Anuario de Historia del Derecho Español, vol. 40, pp. 287311.

De la Hera, Alberto (1980). «El patronato indiano en la historiografía eclesiástica». Hispania Sacra, vol. 32, pp. 229-264.

De la Hera, Alberto (1992). «El patronato y el vicariato regio en Indias». En: Pedro Borges. Historia de la Iglesia en Hispanoamérica y Filipinas (siglos XV-XIX), I: Aspectos generales. Madrid: Biblioteca de Autores Cristianos, I, pp. 63-79. 
De la Hera, Alberto y Rosa María Martínez de Codes (1987). «La Iglesia en el ordenamiento jurídico de las leyes de Indias». En: Recopilación de Leyes de los Reinos de las Indias. Estudios histórico-jurídicos. México: Miguel Ángel Porrúa, pp. 101-140.

De la Peña Montenegro, Alonso (1668). Itinerario de párrocos de indios, en que se tratan las materias más particulares tocantes a ellos para su buena administración. Madrid: Joseph Fernández de Buendía.

De las Casas, Bartolomé (1958). «Avisos y reglas para los confesores». Madrid: Biblioteca de Autores Españoles, pp. 235-248.

De Martinis, Raphael (1888-1897). Iuris Pontificii de Propaganda Fide colectens bullas brevia acta SS. a Congregationis institutione ad praesens juxta temporis seriem disposita auspice Joanne Simeoni. 7 volúmenes. Roma: Ex Typographia Polyglotta.

De Molina, Cristóbal (1584). Confesionario para los curas de indios. Lima.

De Parras, Pedro José (1783). Gobierno de los regulares de la América, ajustado religiosamente a la voluntad del rey. 2 volúmenes. Madrid: Por D. Joachim Ibarra Impresor de Cámara de S. M.

De Rivadeneyra y Barrientos, Antonio Joaquín (1755). Manual compendio del regio patronato indiano para su más fácil uso. Madrid: Antonio Marin.

De Sandoval, Alonso (1627). Naturaleza, policia sagrada y profana, costumbres $i$ ritos, disciplina y catechismo evangélico de todos etípes. Sevilla: Por Francisco de Lira, impresor.

De Solórzano Pereira, Juan (1629). Disputatio de Indiarum iure, sive de iusta Indiarum Occidentialium inquisitione, adquisitione et retentione. Madrid: Fanciscia Martinez.

De Solórzano Pereira, Juan (1639). De Indiarum iure, sive de iusta Indiarum occidentalium gubernatione. Madrid: Fanciscia Martinez.

De Solórzano Pereira, Juan (1647). Política indiana... Madrid: Impr. Diego Días de la Carrera. 
De Tobar, Balthasar (1954-1966). Compendio bulario indico. 2 volúmenes. Sevilla: Escuela de Estudios Hispanoamericanos de Sevilla.

De Utrera, Cipriano (1940). El concilio dominicano de 1622. Sanctiones Concilii Dominicani, con introducción histórica. Ciudad Trujillo [actual Santo Domingo, República Dominicana]: Arquidiócesis de Santo Domingo.

De Vega, Feliciano (1633). Relectionum canonicarum in secundum Decretalium librum. Lima: Jerónimo de Contreras.

De Villanuño, Matías (1785). Summa Conciliorum Hispaniae, quotquot invenire potuerunt ad usque saeculum proxime praeteritum, epistolarum ad Hispanos cum earum delectu. 4 volúmenes. Madrid: Apud Joaquín Ibarra.

De Villanuño, Matías (1850). Summa Conciliorum Hispaniae, quotquot invenire potuerunt ad usque saeculum proxime praeteritum, epistolarum ad Hispanos cum earum delectu. 2 volúmenes. Barcelona: ex Typographia Pauli Riera.

De Villarroel, Gaspar (1656-1657). Gobierno eclesiástico pacífico y unión de dos cuchillos, pontificio y regio. 2 volúmenes. Madrid: Diego García Impresor.

De Zaballa Beascoechea, Ana (2016a). «Introducción. Matrimonio en los siglos XVI-XVIII: derecho canónico, conflictos y realidad social». Revista Complutense de Historia de América, vol. 42, pp. 11-14.

De Zaballa Beascoechea, Ana (2016b). «Una ventana al mestizaje: el matrimonio de los indios en el arzobispado de México, 16601686». Revista Complutense de Historia de América, vol. 42, pp. 73-96.

De Zaballa Beascoechea, Ana (2016c). «Promises and Deceits. Marriage among Indians in the New Spain in the Seventeenth and Eighteenth Centuries». The Americas: A Quarterly Review of Latin American History, vol. 73, pp. 59-82. 
De Zaballa, Ana (2011) (coord.). Los indios, el derecho canónico y la justicia eclesiástica en la América virreinal. Madrid; Frankfurt am Main: Iberoamericana-Vervuert.

De Zárate, Miguel (1736 [1845]). Brevis forma administrandi apud indos sacramenta. Et alia ad sacrum rerum cultum maxime pertinentia: iuxta ordinem S. Romanae Ecclesiae. Quito: Ex typografia Huius P. ac Pont. Universitatis.

De Zurita, Fernando (1586). Theologicarum de Indiis quaestionum, enchiridion primum. Madrid: Gerardo Querino.

Del Corral, Juan (1756). Commentaria in libros Recopilationis indiarum. Madrid: s/e.

Devoti-Corominas, L. (1871). Institutionum canonicarum libri IV ad usum imventutis scholarum insularum Philipinarum. Manila: Typis Collegii Sancti Thomae Sub D. A. Aoiz.

Díaz Vial, Raúl (1962). «Situación de los libros parroquiales». Revista de Estudios Históricos, vol. 10, pp. 109-122.

Donoso, Justo (1848-1849). Instituciones de derecho canónico americano. 2 volúmenes. Valparaíso: Imprenta y librería del Mercurio.

Dougnac Rodríguez, Antonio (2011-2012). «Venecia, el derecho canónico y su proyección en Indias». Revista Chilena de Historia del Derecho, vol. 23, pp. 9-33.

Duve, Thomas (2012). Información bibliográfica para el estudio del derecho canónico indiano. Buenos Aires: Ediciones de las Tres Lagunas.

EnRíQuez, Lucrecia Raquel (2019). «El patronato de la monarquía católica a la república católica chilena (1810-1833)». En: O. Danwerth, B. Albani y T. Duve (eds.), Normatividad e instituciones eclesiásticas en el virreinato del Perú, siglos XVI-XIX. Frankfurt am Main: Max Planck Institute for European Legal History, pp. 233-243. 
ESPONERA, Alfonso (1989). «iLos concilios provinciales americanos realizaron una recepción creativa de Trento?». En: Los sinodos diocesanos del Pueblo de Dios. Actas del V Simposio de Teología Histórica. Valencia: Facultad de Teología San Vicente Ferrer, pp. 345-354.

FerLán, Claudio (2019). «Comunicar la fe. La predicación de los primeros jesuitas entre Austria y Perú (siglo XVI)». En: O. Danwerth, B. Albani y T. Duve (eds.), Normatividad e instituciones eclesiásticas en el virreinato del Perú, siglos XVI-XIX. Frankfurt am Main: Max Planck Institute for European Legal History, pp. 111-134.

Ferreira Ascensio, Claudia (2014). Cuando el cura llama a la puerta. Orden sacramentaly sociedad. Los padrones de confesión del Sagrario de México (16761825). México: El Colegio de México.

FITA, Fidel (1892). «Primeros años del episcopado de América». Boletín de la Real Academia de la Historia, núm. 20, pp. 261-263.

Flores, Alfredo de J. (2018). «Temáticas eclesiales y religiosas en las actas de cabildos seculares de la frontera oriental del virreinato del Río de la Plata». En: Sebastián Terráneo y Osvaldo Moutin (coords.). IV Jornadas de Estudio del Derecho Canónico Indiano. Junín: Ediciones de las Tres Lagunas, pp. 27-50.

FOCHER, Juan (1574). Itinerarium catholicorum profiscicentium, ad infideles convertendos. Sevilla: Apud Alfonsum Scribanum. Versión en castellano: Itinerario del misionero en América. Texto latino con versión castellana, introd. y notas de Antonio Aguilur. Sevilla: Apud Alfonsum Scribanum.

Focher, Juan (1960). Itinerario del misionero en América. Texto latino con versión castellana, introd. y notas de Antonio Aguiluz. Madrid: Colección de libros y documentos referentes a la historia de América.

Frasso, Pedro (1677-1679). De regio patronatu: ac aliis nonnullis regaliis regibus catholicis in indiarum occidentalium imperio pertinentibus, quaestio aliquae desumptae et disputatae. 2 volúmenes. Madrid: Ex Typographia Imperiali apud Josephum Fernández a Buendia. 
FríAS, Susana (2006-2007). «Aranceles eclesiásticos. Normas y costumbre». Investigaciones y Ensayos, vol. 56, pp. 133-162.

FríAs, Susana (2008). «El arancel eclesiástico en Cuyo». Revista de Historia del Derecho, vol. 36, pp. 181-227.

FríAs, Susana (2014). «Las fuentes eclesiásticas. Riqueza y riesgo de su uso». En: M. L. Salinas y M. G. Quiñónez. Fuentes para la historia social, nuevas miradas, nuevas perspectivas. Rosario: Didascalia.

FríAs, Susana (2015). «La visita canónica a los libros parroquiales Buenos Aires 1603-1750». En: Sebastián Terráneo y Osvaldo Moutin (coords.). II Jornadas de Estudio del Derecho Canónico Indiano. Buenos Aires: Ediciones de las Tres Lagunas, pp. 45-75.

FríAs, Susana R. y Sebastián Terráneo (2012). Sínodo de Buenos Aires de 1655. Edición crítica, notas y estudio bistórico-canónico a cargo de. Junín: Ediciones de las Tres Lagunas.

Friedberg, Emil (1959 [1879]). Corpus Iuris Canonici. Graz: Akademische Druck- U. Verlagsanstalt.

Garaveldi, Hugo José (2015). «La expulsión de arzobispos, obispos y eclesiásticos según las leyes de Indias, los juristas de los siglos XVI a XVIII y Juan del Corral Calvo de la Torre». En: Sebastián Terráneo y Osvaldo Moutin (coords.). II Jornadas de Estudio del Derecho Canónico Indiano. Buenos Aires: Ediciones de las Tres Lagunas, pp. 109-130.

García Gallo, Alfonso (1957-1958). «Las bulas de Alejandro VI y el ordenamiento jurídico de la expansión portuguesa y castellana en África e Indias». Anuario de Historia del Derecho Español, vols. 27-28, pp. $799-807$.

García Gutiérrez, Jesús (1941). Apuntes para la historia del origen y desenvolvimiento del regio patronato indiano hasta 1857. México: Escuela Libre de Derecho. 
García Gutiérrez, Jesús (1951). Bulario de la iglesia mejicana. Documentos relativos a erecciones, desmembraciones, etc. de diócesis mejicanas. México: Ed. Buena Prensa.

García y García, Antonio (1982). «Para una interpretación de los concilios y sínodos». En: Juan García de Palacios, Sínodo de Santiago de Cuba de 1681. Madrid; Salamanca: Colección Sínodos Americanos 1, pp. xxi-xxiv.

García y García, Antonio (1985). Iglesia, sociedad y derecho. Salamanca: Bibliotheca Salmanticensis, I, pp. 384-386.

Garrido Aranda, Antonio (1979). Organización de la Iglesia en el reino de Granada y su proyección en Indias. Sevilla: Publicaciones de la Escuela de Estudios Hispanoamericanos.

Giacon, Carlo (1944-1950). La seconda scolastica. 3 volúmenes. Milán: Fratelli Bocca.

Giudice, Hernán (2015). «El uso canónico de los Santos Padres a través del De procuranda indorum salute de José de Acosta». En: Sebastián Terráneo y Osvaldo Moutin (coords.). II Jornadas de Estudio del Derecho Canónico Indiano. Buenos Aires: Ediciones de las Tres Lagunas, pp. 131-146.

Gómez Zamora, Matías (1897). Regio patronato español e indiano. Madrid: Imp. del Asilo de huérfanos del S. C. de Jesús.

GonZÁLEZ, Fernando (2009-2010). «Apuntes liminares de derecho canónico indiano». Anuario Argentino de Derecho Canónico, vol. 16, pp. 269-277.

GonZÁLEz, Fernando (2012). Elementos de derecho canónico indiano en la obra inédita de fray Antonio Comajuncosa «El comisario prefecto de misiones instruido». Junín: Ediciones de las Tres Lagunas.

GonZÁlez, Fernando (2015). «Comentario canónico y público eclesiástico a una real cédula de Carlos III». En: Sebastián Terráneo y Osvaldo Moutin (coords.). II Jornadas de Estudio del Derecho Canónico Indiano. Buenos Aires: Ediciones de las Tres Lagunas, pp. 77-108. 
GonZÁLEZ, Fernando (2018). «Aproximación a las facultades decenales otorgadas a los obispos indianos». En: Sebastián Terráneo y Osvaldo Moutin (coords.). IV Jornadas de Estudio del Derecho Canónico Indiano. Junín: Ediciones de las Tres Lagunas, pp. 93-104.

Grignani, Mario L. (2019). «La legislación eclesiástica de Toribio Alfonso de Mogrovejo, segundo arzobispo de Lima: la Regla consueta y los sínodos diocesanos». En: O. Danwerth, B. Albani y T. Duve (eds.). Normatividad e instituciones eclesiásticas en el virreinato del Perú, siglos XVI-XIX. Frankfurt am Main: Max Planck Institute for European Legal History, pp. 19-42.

Guibovich Pérez, Pedro M. (2011). «Visitas eclesiásticas y extirpación de la idolatría en la diócesis de Lima en la segunda mitad del siglo XVII». En: Ana de Zaballa (coord.). Los indios, el derecho canónico y la justicia eclesiástica en la América virreinal. Madrid; Frankfurt am Main: Iberoamericana-Vervuert, pp. 177-201.

Gutiérrez de Arce, Manuel (1954). «Regio patronato indiano. Ensayo de valoración histórico-canónica». Anuario de Estudios Americanos, vol. 11, pp. 107-168.

Haroldus, Franciscus (1673). Lima Limata. Roma: Tip. Iosephi Corvi.

Hernáez, Francisco Javier (1895). Colección de bulas, breves y otros documentos relativos a la Iglesia en América y Filipinas. Bruselas: Imprenta de Alfredo Vromat, Impresor-Editor.

Hervada, Javier (1987). Historia de la ciencia del derecho natural. Pamplona: Ediciones Universitarias de Navarra.

Hidalgo, Fabián (2005). Tratado de los impedimentos matrimoniales. Córdoba, 1734. (Estudio, transcripción paleográfica y versión española a cargo de S. Benito Moya - G. de Santis). Córdoba: Centro de Estudios Históricos Profesor Carlos S. S. Segreti.

Honores, Renzo (2019). «Litigación en la audiencia arzobispal de Lima: abogados y procuradores de causas en la litigación canónica, 1600- 
1650». En: O. Danwerth, B. Albani y T. Duve (eds.), Normatividad e instituciones eclesiásticas en el virreinato del Perú, siglos XVI-XIX. Frankfurt am Main: Max Planck Institute for European Legal History, pp. 69-110.

KonetzKe, Richard (1946). «Documentos para la historia y crítica de los registros parroquiales en las Indias». Revista de Indias, vol. 7, pp. 581-586.

Latasa, Pilar (2008). «Publicidad y libertad en el matrimonio; autoridad paterna y dispensa de amonestaciones en Lima 1600-1650». En: J. M. Usunariz y R. García Bourreillier (eds.). Padres e hijos en España y el Mundo Hispánico. Siglos XVI y XVIII. Madrid: Visor Libros, pp. 53-67.

LatASA, Pilar (2016a). «Signos y palabras: la celebración del matrimonio tridentino en Lima y Charcas (s. XVI-XVIII)». Revista Complutense de Historia de América, vol. 42, pp. 15-40.

Latasa, Pilar (2016b). «If they remained as mere words: Trent, Marriage, and Freedom in the Viceroyalty of Peru, Sixteenth to Eighteenth Centuries». The Americas: A Quarterly Review of Latin American History, vol. 73, pp. 13-38.

Leturia, Pedro (1959a). «El origen histórico del patronato de Indias». En: Pedro Leturia, Relaciones entre la Santa Sede e Hispanoamérica, 1: Época del real patronato, 1493-1880. Caracas: Sociedad Bolivariana de Venezuela, pp. 3-32.

Leturia, Pedro (1959b). «La bula del patronato de las Indias españolas que falta en el Archivo Vaticano». En: Pedro Leturia. Relaciones entre la Santa Sede e Hispanoamérica, 1: Época del real patronato, 1493-1880. Caracas: Sociedad Bolivariana de Venezuela, pp. 253-258.

LeVILlier, Roberto (1919). Organización de la Iglesia y órdenes religiosas en el virreinato del Perú en el siglo XVI. Documentos del Archivo de Indias. Madrid: Sucesores de Rivadeneyra. 
Martínez de Codes, Rosa María (2008). «Evangelizar y gobernar: el derecho de patronato en Indias». En: Fernando Navarro Antolín (ed.). Orbis incognitus. Avisos y legajos del Nuevo Mundo. Huelva: AEA; Universidad de Huelva, pp. 249-263.

Martínez de Sánchez, Ana María (2008). «Fuentes de archivo para el estudio del derecho canónico indiano local». Revista de Estudios HistóricoJurídicos, vol. 30, pp. 485-503.

Martínez Ferrer, Luis (2015). «Apelaciones del clero de Charcas al Tercer Concilio de Lima (1583-1584)». Annuarium Historiae Conciliorum, vol. 47, pp. 323-370.

Martínez Ferrer, Luis (ed.) (2009). Decretos del concilio tercero provincial mexicano (1585). 2 volúmenes. México: El Colegio de Michoacán; Universidad Pontificia de la Santa Cruz.

Martínez Ferrer, Luis (ed.) y José Luis Gutiérrez (trad.) (2017). Tercer Concilio Limense (1583-1591). Edición bilingüe de los decretos. Lima: Facultad de Teología Pontificia y Civil de Lima.

Mazzoni, María Laura (2019). «La administración diocesana en Córdoba del Tucumán en el período tardocolonial en el marco de la legislación eclesiástica de Lima y Charcas». En: O. Danwerth, B. Albani y T. Duve (eds.). Normatividad e instituciones eclesiásticas en el virreinato del Perú, siglos XVI-XIX. Frankfurt am Main: Max Planck Institute for European Legal History, pp. 201-222.

Metzler, Joseph (1991). America Pontificia. Primi saeculi evangelizationis 14931952. Documenta pontificia ex registris et minutis praesertim in Archivo Secreto Vaticano existentibus. 2 volúmenes. Ciudad del Vaticano: Libreria Editrice Vaticana.

Metzler, Joseph (1995). America Pontificia, III: Documenti pontifici nell'Archivio Segreto Vaticano riguardanti l'evangelizzazione dell'America: 1592-1644. Ciudad del Vaticano: Libreria Editrice Vaticana. 
Mobarec Asfura, Norma (1984). «Libros de derecho canónico en las bibliotecas del reino de Chile». En: Estructura, gobierno y agentes de administración en la América Española (siglos XVI, XVII y XVIII). Actas del VI Congreso Internacional de Historia del Derecho Indiano. Madrid: pp. 95-102.

Morales, Ascencio (1747). Patronato eclesiástico de los reyes de España. Madrid: s/e.

Morales Padrón, Francisco (1979). Teoría y leyes de la conquista. Madrid: Ediciones Cultura Hispánica.

Morel o Morelli, Ciriacus [pseudónimo de Domingo Muriel sj.] (1776). Fasti Novi Orbis et ordinationum apostolicarum ad Indias pertinentium breviarium cum adnotationibus. Venecia: Antonium Zatta.

Moriconi, Miriam (2012). «La administración de la justicia eclesiástica en el Río de la Plata: siglos XVII-XVIII: un horizonte historiográfico». Historia da historiografía, vol. 11, pp. 210-229.

Moriconi, Miriam (2019). «Otra vara de justicia en Santa Fe de la Vera Cruz: los jueces eclesiásticos. Diócesis del Río de la Plata, siglo XVIII». En: O. Danwerth, B. Albani y T. Duve (eds.). Normatividad e instituciones eclesiásticas en el virreinato del Perú, siglos XVI-XIX. Frankfurt am Main: Max Planck Institute for European Legal History, pp. 173-200.

Moutin, Osvaldo (2017). «Procediendo breve y sumariamente, como en causa de indios». En: Sebastián Terráneo y Osvaldo Moutin (coords.). III Jornadas de Estudio del Derecho Canónico Indiano. Junín: Ediciones de las Tres Lagunas, pp. 83-104.

Murillo Velarde, Pedro (1743). Cursus iuris canonici Hispani et Indici, in que iuxta ordinem titulorum Decretalium non solum canonicae decisiones afferuntur, sed insuper additur qiod in nostro Hispania regno et in is Indiarum provincis, lege, consuetudine, privilegio vel praxis statutum et adminissum est. 2 volúmenes. Madrid: Ex typographia Emmanuelis Fernandez. 
Murillo Velarde, Pedro (2005). Curso de derecho canónico hispano e indiano. México: Colegio de Michoacán; Universidad Nacional Autónoma de México.

Olaza Pallero, Sandro (2017). «Presencia del derecho canónico en la justicia penal del Río de la Plata (siglo XVIII)». En: Sebastián Terráneo y Osvaldo Moutin (coords.). III Jornadas de Estudio del Derecho Canónico Indiano. Junín: Ediciones de las Tres Lagunas, pp. 11-62.

Olaza Pallero, Sandro (2018). «Significado y uso del asilo en sagrado en el derecho canónico indiano». En: Sebastián Terráneo y Osvaldo Moutin (coords.). IV Jornadas de Estudio del Derecho Canónico Indiano. Junín: Ediciones de las Tres Lagunas, pp. 105-160.

Pallottini, Salvatoris (1867-1893). Collectio omnium conclusionum et resolutionum quae in causus propositis apud Sacram Congregationem Cardinalium S. Concilii Tridentini interpretum prodierunt ab eius institutione. Roma: Typis S. Congregationis de propaganda fide.

Pereña, Luciano (1987). Carta Magna de los indios. Salamanca: Consejo Superior de Investigaciones Científicas.

Pérez de ARACIEL, García (1624). Información sobre el patronato real de Indias con las bulas tocantes a esta regalía. Madrid: s/e.

PéReZ De la CERDA, Sebastián (1679). Instrucción para los clérigos misioneros de la isla de Cuba. S/l: s/e.

Pérez Miguel, Liliana (2019). «Entre normas y particularidades. El caso del Monasterio de la Concepción de la Ciudad de los Reyes (15731650)». En: O. Danwerth, B. Albani y T. Duve (eds.). Normatividad e instituciones eclesiásticas en el virreinato del Perú, siglos XVI-XIX. Frankfurt am Main: Max Planck Institute for European Legal History, pp. 135-171.

Pizzorusso, Giovanni y Matteo SAnfiLippo (1998). «L'attenzione romana alla Chiesa coloniale Ispano-Americana nell'età di Filippo II». En: José Martínez Millán (dir.). Felipe II (1527-1598). Europa y la monarquía católica. Madrid: Parteluz, pp. 321-340. 
Pizzorusso, Giovanni y Matteo Sanfilippo (2014). «Nuovo Mundo cattolico e Papato: Chiesa coloniale, Chiesa missionaria, Chiesa locale (secoli XVI-inizio XIX)». En: P. Tusor y M. Sanfilippo (ed.). Il papato e le Chiese locali. Studi / The Papacy and the local Churches. Studies. Viterbo: Sette Città, pp. 205-256.

Presta, Ana María (2016). «De casadas a divorciadas. Separaciones, divorcios y nulidades matrimoniales en la sociedad colonial, audiencia de Charcas, 1595-1640». Revista Complutense de Historia de América, vol. 42, pp. 97-118.

Quesada, Vicente Gregorio (1909). Derecho público eclesiástico: derecho de patronato, influencia política y social de la Iglesia católica en América. Buenos Aires.

Ramos, Gabriela (2016). «Pastoral Visitations: Spaces of Negotiation in Andean Indigenous Parishes». The Americas: A Quarterly Review of Latin American History, vol. 73, pp. 39-57.

RoA Barcena, Rafael (1862). Manual teórico-práctico razonado de derecho canónico mexicano: obra escrita con arreglo a los cánones y disposiciones generales de iglesia, al Concilio III mexicano y a las doctrinas de los mejores autores, bajo un plan nuevo al alcance de todos. México: Imprenta Literaria.

Rodríguez Arrocha, Belinda (2019). «Fundamentos del derecho penal en Indias: el Cursus de Murillo Velarde», Revista Ius, vol. 13, pp. 9-31.

Rubiños y ANDRADE, Justo Modesto (1936). «Sucesión cronológica o serie historial de los curas de Mórrope y Pacora en la provincia de Lambayeque del obispado de Trujillo, del Perú [...] con un compendio de las constituciones, breves, decretos, concilios y sinodales, cédulas y leyes que hacen al gobierno espiritual y político de ambos pueblos, por el orden alfabético, 1782». Revista Histórica de Lima, vol. 10, pp. 289-363.

Ruiz, Rafael (2017). «La teología moral y el probabilismo jurídico en la América española de la temprana modernidad». En: Sebastián Terráneo y Osvaldo Moutin (coords.). III Jornadas de Estudio del Derecho Canónico Indiano. Junín: Ediciones de las Tres Lagunas, pp. 63-82. 
Sacrae Congragationis Concilit (1739-1908). Thesaurus Resolutionum Sacrae Congragationis Concilii. 167 volúmenes. Roma: Tipografía Vaticana.

Sacrae Congregationis de Propaganda Fide (1893-1907). Collectanea S. Congregationis de Propaganda Fide. Roma: Ex Typographia Polyglotta S. C. de Prop. Fide.

SÁenz de Aguirre, J. (1754). Collectio maxima Conciliorum omnium Hispaniae et Novis Orbis. 6 volúmenes. Roma: Ex Typographia Antonii Fulgonii apus Saanctum Eustachium.

Salgado de Somoza, Francisco (1646). Tractatus de regia protectione vi oppressorum appellantium a causis et indicibus ecclesiasticis. Lugduni: Sumptibus Laurentii Anison.

Salinas Araneda, Carlos (1984). «Avance para una bibliografía chilena de historia del derecho indiano». Revista de Estudios Histórico-Jurídicos, vol. 9, pp. 303-429.

Salinas Araneda, Carlos (1990-1991). «La protección jurídica de la persona en los sínodos chilenos del período indiano (siglos XVII y XVIII)». Revista Chilena de Historia del Derecho, vol. 16, pp. 169-192.

Salinas Araneda, Carlos (1994a). «El derecho canónico indiano en la bibliografía de una década: apuntes para un balance». Revista de Estudios Histórico-Jurídicos, vol. 16, pp. 164-169.

Salinas Araneda, Carlos (1994b). «El iusnaturalismo hispano-indiano y la protección jurídica de la persona». Anuario Mexicano de Historia del Derecho, vol. 6, pp. 219-237.

Salinas Araneda, Carlos (1998). «La historiografía reciente sobre concilios y sínodos indianos: 1980-1996». Studia Gratiana, núm. 29, pp. 749-750.

Salinas Araneda, Carlos (2000). «Los textos utilizados en la enseñanza del Derecho Canónico en Chile indiano». Anuario de Historia de la Iglesia, vol. 9, pp. 215-234. 
Salinas Araneda, Carlos (2009). «Las relaciones Iglesia-Estado en la América indiana: patronato, vicariato, regalismo». En: Juan G. Navarro Floria (coord.). Estado, derecho y religión en América Latina. Buenos Aires: Marcial Pons, pp. 17-52.

Salinas Araneda, Carlos (2010). «El derecho canónico indiano en la codificación del derecho canónico de 1917 a través de los "postulata" de los obispos chilenos». En: Alejandro Guzmán Brito (ed.). El derecho de las Indias Occidentales y su pervivencia en los derechos patrios de América. Actas del $16^{\circ}$ Congreso del Instituto Internacional de Historia del Derecho Indiano. Tomo 2. Valparaíso: Ediciones Universitarias de Valparaíso, pp. 719-732.

Salinas Araneda, Carlos (2014). Estudios Históricos. El derecho canónico en Chile. Derecho Canónico Indiano. Valparaíso: Pontificia Universidad Católica de Valparaíso.

Salinas Araneda, Carlos (2016). «El nombramiento de obispos en Chile: del derecho indiano a la inadaptación del gobierno chileno a la libertad religiosa». Anuario Jurídico y Económico Escurialense, vol. 49, pp. 189-222.

Salinas Araneda, Carlos (2017). «El derecho indiano en los aportes de los obispos latinoamericanos a la primera codificación del derecho canónico de 1917». En: Thomas Duve (coord.). Actas del XIX Congreso del Instituto Internacional de Historia del Derecho Indiano. Madrid: Dikinson, II, pp. 1597-1615.

SÁnchez BelLa, Ismael (1990). Iglesia y Estado en la América española. Pamplona: Eunsa.

Sanfilippo, M. y G. Pizzorusso (2004). «L'America iberica e Roma fra Cinque e Seicento: notizie, documenti, informatori». En: M. Sanfilippo, A. Koller y G. Pizzorusso (eds.). Gli archivi della Santa Sede e il mondo Asburgico nella prima Età Moderna. Viterbo: Sette Città.

Sastre Santos, Eutimio (2019). «El ius tridentinum (1563-1917) y sus tres variaciones: derecho canónico común, derecho canónico indiano y 
derecho canónico misionero». Revista Española de Derecho Canónico, vol. 76, pp. 755-815.

Scheils, W. Eugene (1961). King and Church: The Rise and Fall of the Patronato Real. Chicago: Literary Lisensig LLC.

Schroeder Cordero, Francisco Arturo (1992). El abogado mexicano, historia e imágenes. México: Universidad Nacional Autónoma de México.

Siegrist, Nora (2011). «Sentencias eclesiásticas. La falta de dispensa por consanguinidad y afinidad en Córdoba del Tucumán y el Río de la Plata. Siglos XVIII-XIX». Temas Americanistas, vol. 27, pp. 49-73.

Siegrist, Nora (2012). «Dictámenes, penas, sentencias y nupcias secretas en las dispensas matrimoniales en territorios de la actual Argentina. Siglos XVIII-XIX». Revista Trocadero, vol. 24, pp. 125-143.

Siegrist, Nora (2015). «El parentesco por afinidad. Aplicación de la doctrina canónica en Córdoba (del Tucumán) en la primera mitad del siglo XIX». En: Sebastián Terráneo y Osvaldo Moutin (coords.). II Jornadas de Estudio del Derecho Canónico Indiano. Buenos Aires: Ediciones de las Tres Lagunas, pp. 11-43.

Siegrist, Nora (2016). «Dispensas y matrimonios secretos en Buenos Aires e Hispanoamérica. Siglo XVIII». Revista Complutense de Historia de América, vol. 42, pp. 41-71.

Tejada y Ramiro, T. (1849-1859). Colección de cánones de la Iglesia de España y América, en latín y castellano con notas e ilustraciones. 6 volúmenes. Madrid: Imprenta de D. Pedro Montero.

Terráneo, Sebastián (2011). «El llamado "III Concilio Provincial Mexicano" y los "Estatutos de la Santa Iglesia de México" o "Reglas consuetas de la catedral de México"». Revista de Estudios Histórico-Jurídicos, vol. 33, pp. 613-637.

Terráneo, Sebastián (2013a). «Los delitos y las penas en los sínodos indianos celebrados en el actual territorio de la República Argentina». Anuario Argentino de Derecho Canónico, vol. 19, pp. 179-217. 
Terráneo, Sebastián (2013b). «Derecho canónico indiano: una hipótesis sobre su naturaleza y contenido». Revista de Historia del Derecho, vol. 46, pp. 99-110.

Terráneo, Sebastián (2014). «La costumbre en el derecho canónico indiano». Anuario Argentino de Derecho Canónico, vol. 20, pp. 271-292.

Terráneo, Sebastián (2015). «El oficio de juez en la iglesia indiana». Anuario Argentino de Derecho Canónico, vol. 21, pp. 357-374.

Terráneo, Sebastián (2016a). «El obispo juez en el derecho canónico indiano. La visita del obispo Juan Gómez de Parada al pueblo de Chiquimula de la Sierra (21 al 30 de enero de 1732)». En: Sociedad Argentina de Derecho Canónico. Jornadas Anuales, Rosario, octubre 2016. Rosario: Sociedad Argentina de Derecho Canónico, pp. 111-136.

Terráneo, Sebastián (2016b). «El proceso de nulidad matrimonial en el derecho canónico indiano. Puntos de contacto con el motu proprio Mitis Iudex Dominus Iesus». Anuario Argentino de Derecho Canónico, vol. 22, pp. 95-117.

TerráneO, Sebastián (2017). «Salus animarun y aequitas canonica como criterios interpretativos del derecho canónico indiano». En: Sebastián Terráneo y Osvaldo Moutin (coords.). III Jornadas de Estudio del Derecho Canónico Indiano. Junín: Ediciones de las Tres Lagunas, pp. 105-122.

Terráneo, Sebastián (2018). «Los adjuntos del cabildo en la diócesis del antiguo Tucumán (1592-1699)». Anuario Argentino de Derecho Canónico, vol. 24, pp. 163-180.

Terráneo, Sebastián (2019a). «El I Sínodo de Buenos Aires (1655)». Archivum, vol. 32, pp. 451.

Terráneo, Sebastián (2019b). «Régimen penal de las asambleas eclesiásticas de Santo Toribio de Mogrovejo». En: Otto Danwerth, Benedetta Albani y Thomas Duve (eds.). Normatividad e instituciones eclesiásticas 
en el virreinato del Perú, siglos XVI-XIX. Frankfurt am Main: Max Planck Institute for European Legal History, pp. 43-68.

TERrÁNeO, Sebastián (2020). Introducción al derecho y a las instituciones eclesiásticas indianas. Buenos Aires: Editorial de la Universidad Católica Argentina.

Terráneo, Sebastián y Osvaldo Moutin (coords.) (2015). II Jornadas de Estudio del Derecho Canónico Indiano. Buenos Aires: Ediciones de las Tres Lagunas.

Terráneo, Sebastián y Osvaldo Moutin (coords.) (2017). III Jornadas de Estudio del Derecho Canónico Indiano. Junín: Ediciones de las Tres Lagunas.

Terráneo, Sebastián y Osvaldo Moutin (coords.) (2018). IV Jornadas de Estudio del Derecho Canónico Indiano. Junín: Ediciones de las Tres Lagunas.

Thieme, Hans (1954). «La significación de los grandes juristas y teólogos españoles del siglo XVI para el descubrimiento del derecho natural». Revista de Derecho Privado, vol. 38, pp. 597-617.

Traslosheros, Jorge E. (2014). Historia judicial eclesiástica de la Nueva España. Materia, método y ražones. México: Universidad Nacional Autónoma de México; Editorial Porrúa; Instituto de Investigaciones Históricas.

Traslosheros, Jorge E. (2016). «Introduction: Canon Law and its Practice in Colonial Latin America». The Americas: A Quarterly Review of Latin American History, vol. 73, pp. 3-11.

Traslosheros, Jorge E. y Ana de Zaballa Beascoechea (coords.). Los indios ante los foros de justicia religiosa en la Hispanoamérica virreinal. México: Universidad Nacional Autónoma de México.

Urteaga, Horacio H. y Domingo Angulo (1925-1942). «Cedulario arzobispal de la archidiócesis de Lima». Revista del Archivo Nacional del Perú, vols. 3-15. 
VÁzquez MendozA, Alejandra Juksdivia (2018). «La desamortización de bienes eclesiásticos en México. Hipótesis de estudio en torno a la defensa de la Iglesia y la justificación del Estado para aplicar la ley». En: Sebastián Terráneo y Osvaldo Moutin (coords.). IV Jornadas de Estudio del Derecho Canónico Indiano. Junín: Ediciones de las Tres Lagunas, pp. 7-26.

VELASCO, V.(1964).«Elconcilio provincial de Charcas de 1629» [equivocadamente dice 1692]. Missionalia Hispanica, vol. 21, pp. 79-180.

Vera, Fortino Hipólito (1887). Colección de documentos eclesiásticos de México, o sea, antigua y moderna legislación de la Iglesia mexicana. 3 volúmenes. Amecameca [México]: Imp. del Colegio Católico, a cargo de Jorge Sigüenza.

Walker, Francisco (1994a). «Visita pastoral del obispo fray Diego de Humanzoro». Anuario de Historia de la Iglesia en Chile, vol. 12, pp. 39-61.

WALKer, Francisco (1994b). «Principales documentos de la visita pastoral del obispo fray Diego de Humanzoro». Anuario de Historia de la Iglesia en Chile, vol. 12, pp. 191-205.

Westermeyer Hernández, Felipe (2016). «Confesionalidad del Estado, real patronato y derecho canónico indiano en las Cortes de Cádiz». Revista de Estudios Histórico-Jurídicos, vol. 38, pp. 445-470.

Wolter, Udo (1975). Ius canonicum in iure civili. Colonia; Viena: Böhlau.

Zamboni, Giovanni Fortunato (1812-1816). Colectio Declarationum Sacrae Congregationis Cardinalium Sacri Concilii Tridentini interpretum. Roma: Typis Caroli Mordacchini.

Fecha de recepción: 29 de julio de 2019.

Fecha de evaluación: 30 de septiembre de 2020.

Fecha de aceptación: 6 de noviembre de 2020.

Fecha de publicación: 30 de junio de 2021.

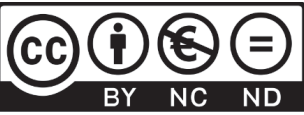

